\title{
Faktor-Faktor Penentu Kepuasan Kerja Karyawan Kontrak Pada Hotel Artotel Sanur Bali
}

\author{
Siti Anggriana ${ }^{1)}$, Ni Made Ariani ${ }^{2)}$ Putu Ratih Pertiwi ${ }^{3)}$ \\ Program Studi Diploma IV Pariwisata, Fakultas Pariwisata, Universitas Udayana ${ }^{123)}$ \\ J1.Dr.R. Goris No.7 Denpasar. Telp / Fax (0361) 22379 \\ Email: sitianggriana@gmail.com
}

\begin{abstract}
Abstrak
Penelitian ini dilakukan diHotel ArtotelSanur Bali yang dilatarbelakangioleh a dan ya fakta bahwa kary awan kontrak yang sudah mencapaikepuasan kerja dibuktikan dengan a danya tingkat turnover rendah di ba wah $10 \%$, tingginya jumlah good comment, penilaian ap praisal rata-rata berada pada ka te gori b a ik, d an a danya hasil survey cukup memuaskan yang dilakukan Artotelgroup. Dilatarbelakangi hal tersebut penelitian ini bermaksud untuk mengetahui faktor-faktor apa saja dan apa faktor dominan yang menentukan kepuas an kerja karyawan kontrak pada Hotel Artotel Sanur Bali. Jenis data yang digunakan data kualit at if dan data kua ntitatif, sumber data primer dan sekunder, dikumpulkan melalui teknik observasi, kuesioner, wa wanca ra, dan dokumentasi. Penentuan informan dengan purposive sampling, penentuan sa mpel dengan sa mpel jenuh/sensus yang berjumlah 63 orang. Teknik a nalisis y ang digunakan skala likert dan teknik analisis faktor konfirmatori. Hasil penelitian menunjukkan bahwa faktor-faktor penentu kepuasan kerja karyawan k ont rak Hotel Artotel Sanur a da empat faktor y aitu 1) faktor individu dan kebijakan perusahaan; 2) faktor sosial da n promosi; 3) faktor organisasi da n manajemen;4) faktor atasan dan komunikasi. Fak tor 1 me miliki nila i eigenva lue $45.360 \%$, faktor 2 memiliki nilai eigen value $1.570 \%$, faktor 3 memiliki nilai eigenvalue $1.372 \%$ dan faktor 4 memiliki nilai eigenvalue $1.210 \%$, keempat faktor tersebut $\mathrm{m}$ ampu menjelaskan $66.116 \%$. Faktor dominan adalah faktor 1 yang terdiri dari 7 indikatory aitu pekerja an meny enangkan, pekerja an menantang, fasilitas karyawan, ra sa hormat, penghargaan, sop penampilan dan cuti. Berd asarkan ja waban yang diberikan responden, saran yang diberikan untuk pihak Hotel Artotel Sanur bahwa senantia sa mempertahankan dan meningkatkan kepuasan kerja karya wan kon trak teruta ma pada faktor dominan tersebut.
\end{abstract}

Kata kunci: Kepuasan Kerja, Karyawan Kontrak, Hotel

\begin{abstract}
This research was conducted at Artotel Sanur Hotel which wa s motivated by the fact, em ployee s of Artotel Sanur have achieved job satisfaction as evidenced by the low turnover ra te below $10 \%$, the high number of good comments, the a verage appraisal assessment is good category, the results of survey were quite satisfactory conducted by Artotelgroup. Aga inst this background, this study intends to fin d o ut what factors are and what is the dominant factors that determine job satisfaction of employees at these Hotel. The type of data is qua litative and quantitative, with primary and secondary data sources, collected through observation, questionnaires, interviews, and documentation. Determination of informants by purposive sa mpling, determination of samples with saturated/census totaling 63 respondents. The a naly sis te ch nique used is likert sca le and confirmatory factor analysis. The results showed that there were four factors, namely: individual factors and company policies; social and promotional factors; organizational a nd management factors; supervisor and communication factors. Fa ctor 1 has a neigenvalue value of $45,360 \%$, factor 2 has an eigenva lue value of $1,570 \%$, factor 3 has an eigenvalue value of $1,372 \%$, factor 4 has a neigenvalue value of $1,210 \%$. These four factors can explain $66,116 \%$. The dominant factor is factor 1 which consists of 7 indicators namely pleasant work, challenging work, employee facilities, respect, appreciation, rules of performance and lea ve. Based on research result, the advicegiven to Artotel Sa nur Hotel is that it a lwa ys maintains and increases job satisfaction of contract employees, especially on these dominant factors.
\end{abstract}

Keywords: Job Satisfaction, ContractEmployees, Hotels 


\section{PENDAHULUAN}

Hotel merupakan salah satu usaha di bidang industri pariwisata. Menurut Sihite (2000: 53) hotel adalah "Jenis akomodasi yang menyediakan fasilitas dan pelayanan penginapan, makan dan minum, serta jasa-jasa lainnya untuk umum yang tinggal untuk sementara waktu dan dikelola secara komersial". Lancarnya usaha hotel ini sangat ditentukan oleh sumber daya manusia (SDM) yang ada di dalamnya. Sumber daya manusia berperan penting dalam sebuah perusahaan. Sumber daya manusia dalam industri perhotelan adalah karyawan. Karyawan adalah aset bagi hotel, aset ini harus dikelola dan dipastikan mendapatkan kepuasan dalam bekerja. Operasional hotel akan berjalan lancar tergantung pada kinerja karyawannya. Kepuasan kerja karyawan sangat penting guna menciptakan citra hotel yang baik.

Menurut Hasibuan (dalam Manullang 2002) "Karyawan merupakan orang penjual jasa "pikiran atau tenaga" dan mendapat kompensasi yang besarnya telah ditetapkan terlebih dahulu". Pen dapat ini senada dengan Kamus Besar Bahasa Indonesia (KBBI) yang menyatakan bahwa "Karyawan merupakan orang yang bekerja pada suatu lembaga "kantor, perusahaan, dan sebagainya" dengan mendapat gaji "upah", pegawai, pekerja. Karyawan akan memberikan kinerja yang memuaskan apabila kepuasan kerjanya sudah tercapai".

Pada industri perhotelan adapun jenis karyawan ada dua yaitu karyawan tetap dan karyawan tidak tetap. Adapun yang dimaksud dengan karyawan tetap adalah karyawan y ang telah memiliki perjanjian kontrak dengan perusahaan dalam jangka waktu yang tidak ditetapkan, Karyawan tidak tetap adalah karyawan yang dipekerjakan oleh perusahaan ketika dibutuhkan dan dapat diberhentikan sewaktu-waktu.

Pada Hotel Artotel Sanur Bali terdapat beberapa fenomena yang berkaitan dengan telah tercapainya kepuasan kerja karyawan kontrak. Adapun jenis tenaga kerja di Hotel Sanur Bali seperti karyawan kontrak, daily worker kontrak, daily worker casual, trainee dan outsourcing. Karyawan kontrak merupakan karyawan yang telah memiliki kontrak/perjanjian kerja dengan pihak Artotel Sanur yang memiliki waktu satu tahun kontrak dan dapat diperbarui setiap tahunnya dengan pertimbangan tertentu.

Hasil rekapan dari Human Resources Departement (HRD) jumlah karyawan kontrak keluar masuk sejak tahun berdirinya Hotel Artotel Sanur Bali tahun 2016 sampai tahun 2018 mengal ami peningkatan dari tiga tahun terakhir.

Tabel 1. Da ta Turnover Karyawan Kontrak di Hotel Artotel Sanur Bali Tahun 2016-2018

\begin{tabular}{cccccc} 
Tahun & $\begin{array}{c}\text { Jumlah } \\
\text { Karyawan } \\
\text { Awal Tahun } \\
\text { (orang) }\end{array}$ & $\begin{array}{c}\text { Jumlah } \\
\text { Karyawan } \\
\text { yang Keluar } \\
\text { (orang) }\end{array}$ & $\begin{array}{c}\text { Jumlah } \\
\text { Karyawan } \\
\text { Masuk } \\
\text { (orang) }\end{array}$ & $\begin{array}{c}\text { Jumlah } \\
\text { Karyawan } \\
\text { Akhir Tahun } \\
\text { (orang) }\end{array}$ & $\begin{array}{c}\text { Turnover } \\
\text { Rate } \\
(\%)\end{array}$ \\
\hline 2016 & 55 & 13 & 18 & 60 & 8,6 \\
\hline 2017 & 60 & 19 & 19 & 60 & 0,0 \\
\hline 2018 & 61 & 20 & 24 & 64 & 6,4 \\
\hline
\end{tabular}

Sumber: Human Resources Departement Hotel Artotel Sanur Bali (2019)

Berdasarkan Tabel 1 di atas, dapat diketahui bahwa dari tahun ke tahun tingkat turnover karyawan fluktuatif sejak tahun berdirinya hotel tersebut. Pada tahun 2016 persentase turnover sebesar 8,6\%. Kemudian pada tahun 2017 mengalami penurunan sehingga persentase turnover sebesar $0,0 \%$. Pada tahun 2018 mengalami kenaikan menjadi 6,4\%. Hal ini terjadi tidak lepas dari kepuasan kerja yang diterima oleh karyawan selama bekerja. Apabila karyawan mendapat kepuasan kerja maka tingkat perputaran atau turnover bisa ditekan dari tahun ke tahun.

Menurut Roesman (1981) menyatakan bahwa "Jika turnover tahunan di dalam satu perusahaan melebihi angka 10\%, maka turnover di dalam perusahaan tersebut dapat dikategorikan tinggi". Jadi apabila persentase turnover masih di bawah $10 \%$ maka turnover di dalam perusahaan tersebut dapat dikategorikan rendah.

Berdasarkan pendapat ahli di atas, dapat diinterpretasikan bahwa turnover Hotel Artotel Sanur Bali tidak berada pada kategori tinggi, atau masih berada pada kategori rendah karena an gka persentase turnover masih di bawah $10 \%$ yaitu pada tahun 2016 sebesar 8,6\%, pada tahun 2017 
sebesar 0,0\%, kemudian tahun 2018 sebesar 6,4\%. Jadi turnover karyawan kontrak Hotel Artotel Sanur Bali masih normal.

Fenomena di atas dapat menjelaskan bahwa masih belum tercapainya kepuasan kerja secara seimbang setiap tahunnya yang dapat menyebabkan turnover karyawan kontrak meningkat. Akan tetapi ada fenomena yang berbeda selama 6 bulan terakhir bahwa banyak terdapat good comment dari tamu yang menerima pelayanan dan fasilitas Hotel Artotel Sanur Bali. Berikut rincian dapat dilihat pada Tabel 2

Tabel2.Data Good Comment TamuEnam Bulan Terakhir November 2018 - April 2019

\begin{tabular}{lll}
\hline No & Bulan & Jumlah(akun) \\
\hline 1 & November & 121 \\
\hline 2 & Desember & 142 \\
\hline 3 & Januari & 118 \\
\hline
\end{tabular}

Sumber: Trustyou system, Human Resources Departement (2019)

Berdasarkan Tabel 2 di atas, dapat diketahui bahwa selama enam bulan terakhir terjadi kenaikan dan penurunan jumlah good comment. Menurut Giese \& Cote (2000: 55) salah satu komponen kepuasan konsumen adalah "Respon (Tipe dan intensitas) yaitu Kepuasan konsumen merupakan respon emosional dan juga kognitif. Intesitas responnya mulai dari sangat puas dan menyukai produk sampai sikap yang apatis terhadap produk tertentu".

Jadi dapat diketahui bahwa data di atas mengungkapkan bahwa tamu yang sudah menerima fasilitas dan pelayanan di Hotel Artotel Sanur Bali lebih banyak memberikan respon yang puas. Pada setiap bulan lebih dari setengah jumlah akun yang memberikan comment menyatakan bahwa mereka puas.

Selain fenomena di atas, adapun Appraisal Form yang diisi oleh atasan masing-masing departemen guna menilai performance karyawan selama bekerja dan dinilai enam bulan satu kali. Karyawan pada level operasional akan dilakukan penilaian oleh manajer masing-masing departemen terkait. Karyawan level manajemen menengah yaitu Head of Department (HOD) seperti manajer departemen akan dilakukan penilaian oleh Bapak Goya A. Mahmud selaku General Manager (GM). Adapun berikut hasil penilaian karyawan perdepartemen selama bekerja dapat dilihat pada Tabel 3 .

Tabel3. Da ta Penilaian Appraisal Karyawan Kontrak (Level manajemen menengah ke operasional) Tahun 2018

\begin{tabular}{llllll}
\hline \multirow{2}{*}{ No } & Departemen & Juli & $\begin{array}{l}\text { Desembe } \\
\text { r }\end{array}$ & Simpulan & Ket. \\
\cline { 3 - 5 } 1 & Front office & 2,64 & 2,66 & Naik 0,02 & Performance \\
\hline 2 & Housekeeping & 2,86 & 2,62 & Turun 0,24 & Performance \\
\hline 3 & F \& B Service & 2,67 & 3,02 & Naik 0,34 & Best Performance \\
\hline 4 & F \& B Product & 2,54 & 2,76 & Naik 0,21 & Performance \\
\hline 5 & Finance & 3,1 & 3,1 & Balance & Best Performance \\
\hline 6 & HR \& security & 2,58 & 2,43 & Turun 0,15 & Performance \\
\hline 7 & Sales \& Marketing & 0 & 2,78 & Naik 2,78 & Performance \\
\hline 8 & Engineering & 2,81 & 2,83 & Naik 0,02 & Performance \\
\hline Sumnnnnnnn
\end{tabular}

Sumber:Human Resources Departement Hotel Artotel Sanur-Bali (2019)

Berdasarkan Tabel 3 di atas dapat diketahui bahwa lima dari delapan departemen mengalami kenaikan performance kerja yaitu departemen front office, food beverage product, food and beverage service, sales and marketing dan engineering. Dua departemen mengalami penurunan yaitu departemen housekeeping dan HR \& security, akan tetapi dua departemen tersebut masih dalam kategori performance. Satu departemen tidak mengalami kenaikan dan peningkatan. Berikut tabel pedoman interpretasi dari keterangan di atas.

Jadi dari adanya hasil Appraisal Form yang dilakukan HRD di atas dapat disimpulkan bahwa pada umumnya karyawan melakukan semua pekerjaan dengan baik sehingga mendapatkan grade PL2 (Performe level 2) atau termasuk kategore performance. Jika semua karyawan dikatakan performance maka ini merupakan salah satu indikator tercapainya kepuasan kerja.

Menurut Robbins (2001:84) menyakan bahwa "Ada empat respon karyawan terhadap kepuasan kerja yaitu: Penilaian untuk tetap bertahan dalam organisasi; tidak melakukan upaya 
menunggu baiknya kondisi organisasi secara pasif; tidak melakukan upaya aktif dan konstruktif untuk memperbaiki kondisi; dan tetap perduli dengan kondisi organisasi”.

Berdasarkan pendapat ahli di atas, jadi dengan adanya perform yang bagus maka secara tidak langsung karyawan sudah melakukan upaya aktif untuk menjaga kondisi organisasi supaya tetap memiliki citra yang baik kepada konsumen. Hal inilah menjadi indikasi bahwa karyawan sudah mencapai kepuasan kerja secara umum.

Adanya tiga fenomena di atas, yaitu jumlah karyawan keluar masuk atau perputaran karyawan (turnover) yang dalam kategori rendah atau normal, jumlah good comment yang fluktiatif, dan penilaian performance karyawan meningkat, maka dapat diketahui bahwa kepuasan kerja karyawan pada beberapa departemen masih belum merata dan maksimal.

Adapun fenomena yang dapat menjelaskan bahwa semua karyawan kontrak Hotel Artotel Sanur Bali rata-rata mendapatkan kepuasan kerja yaitu menurut hasil survey mengenai kepuasan kerja karyawan atau yang sering disebut dengan istilah Artist Satisfaction Survey (ASS) yang dilakukan oleh Artotelgroup atau sering disebut dengan "AG" yang dilaksakan satu kali dalam satu tahun pada semua karyawan kontrak. Adapun hasil survey dapat dilihat pada rincian Tabel 4 di bawah.

Tabel4.Hasil Artist Satisfaction Survey Tahun 2018

\begin{tabular}{ll}
\hline Tahun & Nilai \% \\
\hline 2018 & 80,0 \\
\hline 2019 & 87,5 \\
\hline
\end{tabular}

Sumber: Artist Satisfaction Survey Risult, Artotel Group (2019)

Berdasarkan Tabel 4 di atas, dapat diketahui bahwa hasil survey yang dilakukan oleh Artotelgroup (AG) pada semua properti Artotel yang ada di Indonesia sebanyak 8 properti yaitu Artotel Surabaya, Artotel Yogyakarta, Artotel Sanur Bali, Artotel Tamrin Jakarta, Artotel Haniman Ubud, Artotel Beach Club, De Braga Bandung, dan Alpines Batu. Hotel Artotel Sanur Bali selalu mendapatkan peringkat kedua, pada tahun 2018 dengan perolehan nilai $80 \%$ dan meningkat 7,5\% pada tahun 2019 sehingga menjadi 87,5\%. Dengan adanya hasil survey tersebut, maka dapat diketahui bahwa secara umum karyawan sudah mendapatkan kepuasan kerja selama bekerja di Hotel Artotel Sanur Bali.

Berdasarkan fenomena-fenomena di atas selaras dengan tujuan penelitian ini yaitu untuk mengetahui faktor-faktor apa saja penentu kepuasan kerja karyawan kontrak pada Hotel Artotel Sanur Bali dan faktor dominan penentu kepuasan kerja tersebut. Sehingga pihak manajemen Hotel Artotel Sanur Bali dapat mengetahui apa tindakan untuk kedepannya supaya kepuasan kerja karyawan kontrak selalu meningkat.

\section{METODE PENELITIAN}

Penelitian ini dilakukan di Hotel Artotel Sanur Bali yang terletak di kawasan Sanur yang berlokasi di J1. Kusuma Sari No.1, Sanur, Denpasar Selatan, Kota Denpasar, Bali 80227, contanct (0361) 4721000. Hotel ini merupakan hotel bintang empat (****) dengan jumlah kamar 89 rooms yang terdiri dari suite room 8 unit dan standard room 81 unit. Hotel Artotel Sanur Bali ini merupakan Resort Hotel karena lokasinya yang berdekatan dengan tempat wisata yaitu Pantai Semawang.

Jenis data yang digunakan adalah data kualitatif dan kuantitatif. Sumber data menggunakan data primer dan data skunder yang dihasilkan melalui teknik pengmpulan data observasi, kuesioner, wawancara, dan dokumentasi di lapangan. Penentuan infroman dengan menggunakan teknik purposive sampling yaitu Ibu Maya selaku Cluster Human Resources Departement dan Ibu Nana selaku Human Resources Executiv. Adapun teknik penentuan sampel mmenggunakan teknik sensus atau sampel jenuh yang terdiri dari seluruh karyawan kontrak Hotel Artotel Sanur Bali yang berjumlah 63 orang yang tidak termasuk General Manager. Teknik analisis data yang digunakan dalam penelitian ini adalah analisis data deskriptif kuantitatif yaitu; 1) statistik deskriptif menggunakan skala likert; 2) Statistik inferensial menggunakan analisis faktor konfirmatori. Sebelum melakukan teknik analisis tersebut, hal yang akan dilakukan adalah uji instrumen yaitu uji validitas dan uji realiabilitas. 


\section{HASIL DAN PEMBAHASAN}

\subsection{Kepuasan Kerja Karyawan Kontrak Hotel Artotel Sanur Bali}

Kepuasan kerja karyawan kontrak Hotel Artotel Sanur Bali diukur dengan menggunakan skala pengukuran sikap, yaitu berupa Skala Likert. Pada pengukuran menggunakan skala likert ini terdapat 10 variabel yangmenentukan kepuasan kerja karyawan kontrak Hotel Artotel Sanur Bali yaitu gaji, pekerjaan itu sendiri, rekan kerja, atasan, promosi, lingkungan kerja, benefit, contingent rewards, operating procedures, dan communication.

3.1.1 Kepuasan Kerja Karyawan Kontrak Berdasarkan Gaji

Kepuasan kerja karyawan kontrak Hotel Artotel Sanur Bali berdasarkan gaji dapat dilihat dari hasil kuesioner yang dihitung melalui analisis skala likert. Adapun rinciannya dapat dilihat pada tabel berikut.

Tabel5. Kepuasan Kerja Karyawan Kontrak Hotel Artotel Sa nur Bali Berdasarkan Gaji

\begin{tabular}{|c|c|c|c|c|c|c|c|c|c|}
\hline \multirow{2}{*}{$\begin{array}{l}\mathrm{N} \\
\mathrm{O}\end{array}$} & \multirow[b]{2}{*}{ India tor } & \multicolumn{5}{|c|}{ Penilaian } & \multirow[b]{2}{*}{ Skor } & \multirow{2}{*}{$\begin{array}{l}\text { Rata- } \\
\text { rata }\end{array}$} & \multirow[b]{2}{*}{ Kategori } \\
\hline & & STP & $\mathrm{TP}$ & $\mathrm{CP}$ & $\mathrm{P}$ & SP & & & \\
\hline 1 & Gaji & & & & & & & & \\
\hline $\mathrm{a}$ & $\begin{array}{l}\text { Keterlibatan Dalam } \\
\text { Pembangunan Akomodasi }\end{array}$ & 0 & 2 & 18 & 34 & 9 & 239 & 3,79 & Puas \\
\hline $\mathrm{b}$ & $\begin{array}{l}\text { DampakPembangunan } \\
\text { Akomodasi Terhadap } \\
\text { Kesejahteraan }\end{array}$ & 0 & 0 & 1 & 27 & 35 & 286 & 4,53 & $\begin{array}{l}\text { Sangat } \\
\text { Puas }\end{array}$ \\
\hline $\mathrm{Ra}$ & ta-rata & & & & & & 262,50 & 4,16 & Puas \\
\hline
\end{tabular}

Sumber:Hasil penelitian (2019)

Berdasarkan Tabel 5 di atas, dapat dilihat bahwa indikator besaran gaji yang diterima karyawan kontrak mendapatkan skor 3,79 dengan kategori puas. Indikator kedua yaitu ketepatan waktu menerima gaji mendapatkan skor 4,53 dengan kategori sangat puas. Skor rata-rata penilaian karyawan kontrak Hotel Artotel Sanur Bali berdasarkan gaji adalah 4,16. Sehingga dapat dikatakan bahwa karyawan kontrak menyatakan puas dengan gaji yang diberikan perusahaan. Hal ini terjadi karena banyak responden yang memberikan penilaian pada kategori puas dan sangat puas.

Hasil kuesioner di atas didukung juga oleh hasil wawancara dengan informan yaitu Ibu Maya Putri Septiani selaku Cluster Human Resources Manager sebagai berikut:

"Saya selalu closing gaji karyawan sebelum tanggal 25 dengan human resources executive, supaya semua karyawan mendapatkan gaji mereka tepat pada tanggal 25 setiap bulannya. (Wawancara, 2 Agustus 2019)"

Jadi dapat disimpulkan bahwa seluruh karyawan kontrak Hotel Artotel Sanur Bali sudah merasakan kepuasan terhadap besaran gaji yang diterima setiap bulannya dan ketepatan waktu menerima gaji tersebut.

\subsubsection{Kepuasan Kerja Karyawan Kontrak Berdasarkan Pekerjaan itu Sendiri}

Kepuasan kerja karyawan kontrak Hotel Artotel Sanur Bali berdasarkan pekerjaan itu sendiri dapat dilihat dari hasil kuesioner yang dihitung melalui analisis skala likert. Adapun rinciannya dapat dilihat pada tabel berikut.

Tabel6. Kepuasan Kerja Karyawan Kontrak Hotel Artotel Sa nur Bali Berdasarkan Pekerjaan itu Sendiri

\begin{tabular}{|c|c|c|c|c|c|c|c|c|c|}
\hline \multirow{2}{*}{$\begin{array}{l}\mathrm{N} \\
\mathrm{O}\end{array}$} & \multirow{2}{*}{ India tor } & \multicolumn{5}{|c|}{ Penilaian } & \multirow{2}{*}{ Skor } & \multirow{2}{*}{$\begin{array}{l}\text { Rata- } \\
\text { rata }\end{array}$} & \multirow{2}{*}{ Kategori } \\
\hline & & STP & $\mathrm{TP}$ & $\mathrm{CP}$ & $\mathrm{P}$ & SP & & & \\
\hline 1 & Gaji & & & & & & & & \\
\hline $\mathrm{a}$ & $\begin{array}{l}\text { Pekerjaanyang } \\
\text { menyenangkan /tidak } \\
\text { Membosankan }\end{array}$ & 0 & 0 & 2 & 44 & 17 & 267 & 4,23 & $\begin{array}{l}\text { Sangat } \\
\text { Puas }\end{array}$ \\
\hline b & Pekerjaan yang menantang & 0 & 0 & 4 & 41 & 18 & 266 & 4,22 & $\begin{array}{l}\text { Sangat } \\
\text { Puas }\end{array}$ \\
\hline & a-rata & & & & & & 266,50 & 4,16 & $\begin{array}{l}\text { Sangat } \\
\text { Puas }\end{array}$ \\
\hline
\end{tabular}

Sumber:Hasil penelitian (2019) 
Berdasarkan Tabel 6 di atas, dapat dilihat bahwa indikator pekerjaan yang menyenangkan/tidak membosankan yang dirasakan karyawan kontrak mendapatkan skor 4,23 dengan kategori sangat puas. Indikator kedua yaitu pekerjaan yang menantang mendapatkan skor 4,22 dengan kategori sangat puas. Skor rata-rata penilaian karyawan kontrak Hotel Artotel Sanur Bali berdasarkan pekerjaan itu sendiri adalah 4,22. Sehingga dapat dikatakan bahwa karyawan kontrak menyatakan sangat puas dengan pekerjaan itu sendiri selama bekerja di Hotel Artotel Sanur Bali.

3.1.3 Kepuasan Kerja Karyawan Kontrak Berdasarkan Rekan Kerja

Kepuasan kerja karyawan kontrak Hotel Artotel Sanur Bali berdasarkan rekan kerja dapat dilihat dari hasil kuesioner yang dihitung melalui analisis skala likert. Adapun rinciannya dapat dilihat pada tabel berikut.

Tabel 7. Kepuasan Kerja Karyawan Kontrak Hotel Artotel Sanur Bali Berdasarkan Rekan Kerja

\begin{tabular}{|c|c|c|c|c|c|c|c|c|c|}
\hline \multirow[b]{2}{*}{ No } & \multirow[b]{2}{*}{ Indikator } & \multicolumn{5}{|c|}{ Penilaian } & \multirow[b]{2}{*}{ Skor } & \multirow{2}{*}{$\begin{array}{l}\text { Rata } \\
\text { Rata }\end{array}$} & \multirow[b]{2}{*}{ Kategori } \\
\hline & & STP & TP & CP & $\mathrm{P}$ & SP & & & \\
\hline 1 & \multicolumn{9}{|l|}{ Rekan Kerja } \\
\hline $\mathrm{a}$ & $\begin{array}{l}\text { Rekan kerja yang } \\
\text { menyenangkan }\end{array}$ & 0 & 0 & 8 & 32 & 23 & 267 & 4,23 & SangatPuas \\
\hline $\mathrm{b}$ & $\begin{array}{l}\text { Bekerjasama dengan } \\
\text { la ncar (bertanggung } \\
\text { ja wab, dukungan dari } \\
\text { rekan kerja) }\end{array}$ & 0 & 0 & 8 & 31 & 24 & 268 & 4,25 & SangatPuas \\
\hline & Rata & & & & & & 267,20 & 4,24 & SangatPuas \\
\hline
\end{tabular}

Sumber: Hasilpenelitian(2019)

Berdasarkan Tabel 7 di atas, dapat dilihat bahwa indikator rekan kerja yang menyenangkan yang dirasakan karyawan kontrak mendapatkan skor 4,23 dengan kategori sangat puas. Indikator kedua yaitu bekerjasama dengan lancar mendapatkan skor 4,25 dengan kategori sangat puas, adapun yang dimaksud dengan bekerjasama dengan lancar adalah rasa tanggung jawab yang besar dan dukungan dari rekan kerja selama menyelesaikan suatu pekerjaan secara bersamasama.

Skor rata-rata penilaian karyawan kontrak Hotel Artotel Sanur Bali berdasarkan rekan kerja adalah 4,24. Sehingga dapat dikatakan bahwa karyawan kontrak menyatakan sangat puas dengan rekan kerja selama bekerja di Hotel Artotel Sanur Bali. Hal ini terjadi karena banyak responden yang memberikan penilaian pada kategori puas dan sangat puas.

3.1.4 Kepuasan Kerja Karyawan Kontrak Berdasarkan Atasan

Kepuasan kerja karyawan kontrak Hotel Artotel Sanur Bali berdasarkan atasan dapat dilihat dari hasil kuesioner yang dihitung melalui analisis skala likert. Adapun rinciannya dapat dilihat pada Tabel 8 berikut.

Tabel 8. Kepuasan Kerja Karyawan Kontrak Hotel Artotel Sanur Ba li Berdasarkan Atasan

\begin{tabular}{|c|c|c|c|c|c|c|c|c|c|}
\hline \multirow{2}{*}{ No } & \multirow{2}{*}{ Indikator } & \multicolumn{4}{|c|}{ Penilaian } & & \multirow{2}{*}{ Skor } & \multirow{2}{*}{$\begin{array}{l}\text { Rata- } \\
\text { Rata }\end{array}$} & \multirow{2}{*}{ Kategori } \\
\hline & & STP & TP & $\mathrm{CP}$ & $\mathrm{P}$ & SP & & & \\
\hline 1 & Atasan & & & & & & & & \\
\hline$a$ & $\begin{array}{l}\text { Ata san senantiasa } \\
\text { memberikan petunjuk } \\
\text { da la m melaksanakan } \\
\text { pekerjaan }\end{array}$ & 0 & 0 & 7 & 31 & 25 & 270 & 4,28 & Sangat Puas \\
\hline $\mathrm{b}$ & $\begin{array}{l}\text { Sistem pengawasan } \\
\text { tegas dalam } \\
\text { menegakkan } \\
\text { disiplin dan secara terus } \\
\text { menerus }\end{array}$ & 0 & 0 & 2 & 38 & 23 & 273 & 4,33 & Sa ngat Puas \\
\hline $\mathrm{Ra}$ & Rata & & & & & & 271,50 & 4,30 & SangatPuas \\
\hline
\end{tabular}

Sumber:Hasil penelitian (2019)

Berdasarkan Tabel 8 di atas, dapat dilihat bahwa indikator atasan senantiasa memberikan petunjuk dalam melaksanakan pekerjaan mendapatkan skor 4,28 dengan kategori sangat puas. Adapun yang dimaksud dengan pemberian petunjuk seperti, atasan petunjuk cara handling tamu yang baik dan 
benar, cara mengoperasikan alat kerja, dan petunjuk lainnya yang sesuai dengan departemen masing-masing. Indikator kedua yaitu sistem pengawasan tegas dalam menegakkan disiplin dan secara terus menerus mendapatkan skor 4,33 dengan kategori sangat puas.

Skor rata-rata penilaian karyawan kontrak Hotel Artotel Sanur Bali berdasarkan atasan adalah 4,30. Sehingga dapat dikatakan bahwa karyawan kontrak menyatakan sangat puas dengan atasan selama bekerja di Hotel Artotel Sanur Bali. Hal ini terjadi karena banyak responden yang memberikan penilaian pada kategori puas dan sangat puas.

Hasil kuesioner di atas didukung juga oleh hasil wawancara dengan informan yaitu Ibu Maya Putri Septiani selaku Cluster Human Resources Manager sebagai berikut:

"Ya kami selalu mengawasi secara tegas dan selalu itu terus menerus sama semuanya. (Wawancara, 2 Agustus 2019)"

Jadi dapat disimpulkan bahwa dari sistem manajemen sudah melakukan sistem pengawasan yang ketat dan secara terus-menerus, begitupun dengan ke level operasional sehingga pada indikator atasan ini seluruh karyawan merasa puas dengan sikap pimpinan dan sistem pengawasannya.

3.1.5 Kepuasan Kerja Karyawan Kontrak Berdasarkan Promosi

Kepuasan kerja karyawan kontrak Hotel Artotel Sanur Bali berdasarkan promosi dapat dilihat dari hasil kuesioner yang dihitung melalui analisis skala likert. Adapun rinciannya dapat dilihat pada tabel berikut.

Tabe19. Kepuasan Kerja Karyawan Kontrak Hotel Artotel Sanur Bali Berdasarkan Promosi

\begin{tabular}{|c|c|c|c|c|c|c|c|c|c|}
\hline \multirow[b]{2}{*}{ No } & \multirow[b]{2}{*}{ Indikator } & \multicolumn{5}{|c|}{ Penilaian } & \multirow[b]{2}{*}{ Skor } & \multirow{2}{*}{$\begin{array}{l}\text { Rata } \\
- \\
\text { Rata }\end{array}$} & \multirow[b]{2}{*}{ Kategori } \\
\hline & & $\begin{array}{l}\text { ST } \\
\text { P }\end{array}$ & $\mathrm{TP}$ & $\mathrm{CP}$ & $\mathrm{P}$ & SP & & & \\
\hline 1 & \multicolumn{9}{|l|}{ Promosi } \\
\hline $\mathrm{a}$ & $\begin{array}{l}\text { Kebijakan promosi } \\
\text { yangbagi siapa saja } \\
\text { secara adil }\end{array}$ & 0 & 1 & 9 & 37 & 16 & 257 & 4,07 & Puas \\
\hline $\mathrm{b}$ & $\begin{array}{l}\text { Manajemen } \\
\text { memberikan } \\
\text { kesempatan dan } \\
\text { memfasilitasiuntuk } \\
\text { belajar }\end{array}$ & 0 & 0 & 2 & 35 & 26 & 276 & 4,38 & SangatPuas \\
\hline Ratc & Rata & & & & & & 266,50 & 4,22 & SangatPuas \\
\hline
\end{tabular}

Sumber:Hasilpenelitian (2019)

Berdasarkan Tabel 9 di atas, dapat dilihat bahwa indikator kebijakan promosi yang bagi siapa saja secara adil mendapatkan skor 4,07 dengan kategori puas. Indikator kedua yaitu manajemen memberikan kesempatan dan memfasilitasi untuk belajar mendapatkan skor 4,38 dengan kategori sangat puas. Yang dimaksud dengan manajemen memberikan kesempatan dan memfasilitasi untuk belajar seperti, manajemen memberikan kesempatan dan dukungan baik mental dan biaya untuk semua karyawan dalam belajar mengembangkan skill yang dimiliki. Skor rata-rata penilaian karyawan kontrak Hotel Artotel Sanur Bali berdasarkan promosi adalah 4,22. Sehingga dapat dikatakan bahwa karyawan kontrak menyatakan sangat puas dengan promosi selama bekerja di Hotel Artotel Sanur Bali.

Hasil kuesioner di atas didukung juga oleh hasil wawancara dengan informan yaitu Ibu Maya Putri Septiani selaku Cluster Human Resources Manager sebagai berikut:

"Kami memberikan fasilitas belajar untuk karyawan kontrak, seperti Mang Tete yang akan kami berangkatkan ke Jakarta untuk belajar dan mengasah skillnya sebagai seorang Bartender. Ini semuanya dibiayai oleh perusahaan, jadi karyawan kami hanya perlu menyiapkan diri untuk belajar kesana. (Wawancara, 2 Agustus 2019)"

Jadi dapat disimpulkan bahwa pada indikator promosi ini sudah berjalan dengan baik sehingga seluruh karyawan kontrak merasa puas dengan kebijakan promosi yang ada dan puas juga dengan fasilitas belajar yang disediakan. 
3.1.6 Kepuasan Kerja Karyawan Kontrak Berdasarkan Lingkungan Kerja

Kepuasan kerja karyawan kontrak Hotel Artotel Sanur Bali berdasarkan lingkungan kerja dapat dilihat dari hasil kuesioner yang dihitung melalui analisis skala likert. Adapun rinciannya dapat dilihat pada tabel berikut.

Tabel 10. Kepuasan Kerja Karyawan Kontrak Hotel Artotel Sa nur Bali Berdasarkan Lingkungan Kerja

\begin{tabular}{|c|c|c|c|c|c|c|c|c|c|}
\hline \multirow[b]{2}{*}{ No } & \multirow[b]{2}{*}{ Indikator } & \multicolumn{5}{|c|}{ Penilaian } & \multirow[b]{2}{*}{ Skor } & \multirow{2}{*}{$\begin{array}{l}\text { Rata- } \\
\text { Rata }\end{array}$} & \multirow[b]{2}{*}{ Kategori } \\
\hline & & STP & TP & $\mathrm{CP}$ & $\mathrm{P}$ & SP & & & \\
\hline 1 & \multicolumn{9}{|l|}{ Lingkungan Kerja } \\
\hline $\mathrm{a}$ & $\begin{array}{l}\text { Lingkungan kerja } \\
\text { yangaman dan } \\
\text { nyaman }\end{array}$ & 0 & 0 & 12 & 25 & 26 & 266 & 4,22 & $\begin{array}{l}\text { Sangat } \\
\text { Puas }\end{array}$ \\
\hline $\mathrm{b}$ & $\begin{array}{l}\text { Tersedianya } \\
\text { fasilitas tempat } \\
\text { istirahat, kantin, } \\
\text { tempatibadah yang } \\
\text { nyaman }\end{array}$ & 0 & 0 & 3 & 36 & 24 & 273 & 4,33 & $\begin{array}{l}\text { Sangat } \\
\text { Puas }\end{array}$ \\
\hline & & & & & & & 269,50 & 4,27 & $\begin{array}{l}\text { Sangat } \\
\text { Puas }\end{array}$ \\
\hline
\end{tabular}

Sumber: Hasilpenelitian(2019)

Berdasarkan Tabel 10 di atas, dapat dilihat bahwa indikator lingkungan kerja yang aman dan nyaman mendapatkan skor 4,22 dengan kategori sangat puas. Indikator kedua yaitu tersedianya fasilitas tempat istirahat, kantin, tempat ibadah yang nyaman mendapatkan skor 4,33 dengan kategori sangat puas. Skor rata-rata penilaian karyawan kontrak Hotel Artotel Sanur Bali berdasarkan lingkungan kerja adalah 4,27. Sehingga dapat dikatakan bahwa karyawan kontrak menyatakan sangat puas dengan lingkungan kerja selama bekerja di Hotel Artotel Sanur Bali.

Hasil kuesioner di atas didukung juga oleh hasil wawancara dengan informan yaitu Ibu Maya Putri Septiani selaku Cluster Human Resources Manager sebagai berikut:

"Fasilitas untuk karyawan seperti loker sudah bagus, kami sediakan karpet untuk tidur sejanak saat break, kami sediakan 2 rak sepatu supaya selalu rapi, dan beberapa saya pasang sign supaya loker tetap aman, nyaman, bersih dan rapi, seperti larangan membawa makanan dan minuman, lar angan menaikkan sepatu ke karpet. Mengenai tempat parkir, kami menyediakan di luar gedung Artotel ini, kami sewa gedung didekat sini, karena area parkir disini hanya cukup untuk tamu saja. Sudah cukup nyamanlah. (Wawancara, 2 Agustus 2019)"

Jadi dapat disimpulkan bahwa pada indikator lingkungan kerja ini sudah berjalan dengan baik sehingga seluruh karyawan kontrak merasa puas dengan kondisi lingkungan kerja dan fasilitas yang disediakan untuk karyawan.

3.1.7 Kepuasan Kerja Karyawan Kontrak Berdasarkan Benefit

Kepuasan kerja karyawan kontrak Hotel Artotel Sanur Bali berdasarkan gaji dapat dilihat dari hasil kuesioner yang dihitung melalui analisis skala likert. Adapun rinciannya dapat dilihat pada tabel berikut.

Tabel 11. Kepuasan Kerja Karyawan Kontrak Hotel Artotel Sa nur Bali Berdasarkan Benefit

\begin{tabular}{|c|c|c|c|c|c|c|c|c|c|}
\hline \multirow[b]{2}{*}{ No } & \multirow[b]{2}{*}{ Indikator } & \multicolumn{5}{|c|}{ Penilaian } & \multirow[b]{2}{*}{ Skor } & \multirow{2}{*}{$\begin{array}{l}\text { Rata- } \\
\text { Rata }\end{array}$} & \multirow[b]{2}{*}{ Kategori } \\
\hline & & STP & $\mathrm{TP}$ & $\mathrm{CP}$ & $\mathrm{P}$ & SP & & & \\
\hline 1 & \multicolumn{9}{|l|}{ Benefit } \\
\hline $\mathrm{a}$ & $\begin{array}{l}\text { Perusahaan } \\
\text { memberikan asuransi }\end{array}$ & 0 & 0 & 3 & 40 & 20 & 269 & 4,26 & $\begin{array}{l}\text { Sangat } \\
\text { Puas }\end{array}$ \\
\hline $\mathrm{b}$ & $\begin{array}{l}\text { Perusahaan } \\
\text { mengadakan } \\
\text { gathering secara } \\
\text { berkala }\end{array}$ & 0 & 0 & 10 & 37 & 16 & 258 & 4,09 & Puas \\
\hline \multicolumn{7}{|c|}{ Rata-Rata } & 263,50 & 4,17 & Puas \\
\hline
\end{tabular}

Sumber:Hasilpenelitian(2019) 
Berdasarkan Tabel 11 di atas, dapat dilihat bahwa indikator perusahaan memberikan asuransi mendapatkan skor 4,26 dengan kategori sangat puas. Indikator kedua yaitu perusahaan mengadakan gathering secara berkala mendapatkan skor 4,09 dengan kategori puas. Skor rata-rata penilaian karyawan kontrak Hotel Artotel Sanur Bali berdasarkan benefit adalah 4,17. Sehingga dapat dikatakan bahwa karyawan kontrak menyatakan puas dengan benefit selama bekerja di Hotel Artotel Sanur Bali.

Hasil kuesioner di atas didukung juga oleh hasil wawancara dengan informan yaitu Ibu Maya Putri Septiani selaku Cluster Human Resources Manager sebagai berikut:

"Kami memberikan asuransi BPJS Ketenagakerjaan, BPJS Kesehatan dan ada juga namanya MAG. BPJS itu kami berikan untuk seluruh karyawan kontrak dan asuransi MAG itu bagi karyawan yang mau saja, kalau mau ya kami daftarkan. Untuk Gathering kami selalu adakan kok, contohnya pas ulang tahun Artotel selalu kami rayakan di luar sama karyawan yang lain. (Wawancara, 2 Agustus 2019)"

Jadi dapat disimpulkan bahwa pada indikator benfit ini sudah berjalan dengan baik sehingga seluruh karyawan kontrak merasa puas dengan asuransi yang didapat dan gathering yang selalu diselenggarakan perusahaan.

\subsubsection{Kepuasan Kerja Karyawan Kontrak Berdasarkan Contingent Reawards}

Kepuasan kerja karyawan kontrak Hotel Artotel Sanur Bali berdasarkan contingent rewards dapat dilihat dari hasil kuesioner yang dihitung melalui analisis skala likert. Adapun rinciannya dapat dilihat pada tabel berikut.

Tabel 12. Kepuasan Kerja Karyawan Kontrak Hotel Artotel Sa nur Bali Berdasarkan Contingent Rewards

\begin{tabular}{|l|l|l|l|l|l|l|l|l|l|l|}
\hline \multirow{2}{*}{ No } & \multirow{2}{*}{\begin{tabular}{l} 
Indikator \\
\cline { 3 - 10 }
\end{tabular}} & STP & TP & CP & P & SP & Skor & $\begin{array}{l}\text { Rata } \\
\text { Rata }\end{array}$ & Kategori \\
\hline 1 & Contingent Rewards & $\begin{array}{l}\text { Pasa hormat kepada } \\
\text { rekan kerja dan atasan }\end{array}$ & 0 & 0 & 10 & 31 & 22 & 264 & 4,19 & Puas \\
\hline a & $\begin{array}{l}\text { Perusahaan memberkan } \\
\text { penghargaan atas } \\
\text { presta si yang didapat } \\
\text { oleh karyawan }\end{array}$ & 0 & 0 & 2 & 46 & 15 & 265 & 4,20 & Puas \\
\hline Rata-Rata & & & & & & & 264,50 & 4,19 & Puas \\
\hline
\end{tabular}

Sumber:Hasilpenelitian(2019)

Berdasarkan Tabel 12 di atas, dapat dilihat bahwa indikator rasa hormat kepada rekan kerja dan atasan mendapatkan skor 4,19 dengan kategori puas. Indikator kedua yaitu perusahaan memberikan penghargaan atas prestasi yang didapat oleh karyawan mendapatkan skor 4,20 dengan kategori puas. Skor rata-rata penilaian karyawan kontrak Hotel Artotel Sanur Bali berdasarkan contingent rewards adalah 4,19. Sehingga dapat dikatakan bahwa karyawan kontrak menyatakan puas dengan contingent rewards selama bekerja di Hotel Artotel Sanur Bali.

Hasil kuesioner di atas didukung juga oleh hasil wawancara dengan informan yaitu Ibu Maya Putri Septiani selaku Cluster Human Resources Manager sebagai berikut:

"Rasa hormat pada atasan atasan, bawahan dan rekan kerja pasti ada. Rewards yang kami berikan jenisnya banyak, ada yang best artist dan best supervisor yang dilakukan per 4 bulan sekali dan satu tahun sekali. Ada juga best comment yang human resouces executive rekap satu kali dalam 4 bulan dari system namanya trstyou. Ini biasanya kami kasi penghargaan ada yang berupa uang tunai dan hadiah lainnya. (Wawancara, 2 Agustus 2019)"

Jadi dapat disimpulkan bahwa pada indikator contingent rewards ini sudah berjalan dengan baik terlihat dengan cara manajemen memberikan berbagai jenis rewards kepada karyawan sehingga seluruh karyawan kontrak merasa puas selama bekerja di Hotel Artotel Sanur Bali.

3.1.9 Kepuasan Kerja Karyawan Kontrak Berdasarkan Operating Procedure 
Kepuasan kerja karyawan kontrak Hotel Artotel Sanur Bali berdasarkan contingent rewards dapat dilihat dari hasil kuesioner yang dihitung melalui analisis skala likert. Adapun rinciannya dapat dilihat pada tabel berikut.

Tabel 13. Kepuasan Kerja Karyawan Kontrak Hotel Artotel Sanur Bali Berdasarkan Operating Procedures

\begin{tabular}{|c|c|c|c|c|c|c|c|c|c|}
\hline \multirow[b]{2}{*}{ No } & \multirow{2}{*}{ Indikator } & \multicolumn{5}{|c|}{ Penilaian } & \multirow{2}{*}{ Skor } & \multirow{2}{*}{$\begin{array}{l}\text { Rata } \\
- \\
\text { Rata }\end{array}$} & \multirow[b]{2}{*}{ Kategori } \\
\hline & & STP & $\mathrm{TP}$ & $\mathrm{CP}$ & $\mathrm{P}$ & SP & & & \\
\hline 1 & \multicolumn{9}{|l|}{ Operating Procedures } \\
\hline $\mathrm{a}$ & $\begin{array}{l}\text { Ada nya a turan } \\
\text { standar penampilan } \\
\text { dan pemakaian baju } \\
\text { adat }\end{array}$ & 0 & 0 & 0 & 30 & 33 & 285 & 4,52 & SangatPuas \\
\hline $\mathrm{b}$ & $\begin{array}{l}\text { Ada nyan aturan } \\
\text { da la m bekerja dan } \\
\text { penga mbilan cuti }\end{array}$ & 0 & 0 & 2 & 22 & 39 & 289 & 4,58 & SangatPuas \\
\hline \multicolumn{7}{|c|}{ Rata-Rata } & 287 & 4,55 & SangatPuas \\
\hline
\end{tabular}

Sumber:Hasilpenelitian(2019)

Berdasarkan Tabel 13 di atas, dapat dilihat bahwa indikator adanya aturan standar penampilan dan pemakaian baju adat mendapatkan skor 4,52 dengan kategori sangat puas. Indikator kedua yaitu adanyan aturan dalam bekerja dan pengambilan cuti mendapatkan skor 4,58 dengan kategori sangat puas. Skor ratarata penilaian karyawan kontrak Hotel Artotel Sanur Bali berdasarkan contingent rewards adalah 4,55. Sehingga dapat dikatakan bahwa karyawan kontrak menyatakan sangat puas dengan operating procedures selama bekerja di Hotel Artotel Sanur Bali.

Hasil kuesioner di atas didukung juga oleh hasil wawancara dengan informan yaitu Ibu Maya Putri Septiani selaku Cluster Human Resources Manager sebagai berikut:

"Semuanya ada prosedurnya, baik cara berpakaian seperti kami menerapkan kalau hari kamis khusus karyawan Front Office wajib menggunakan pakaian adat. Kemudian untuk pengambilan cuti juga ada prosedurnya, harus menggunakan form yang harus disetujui oleh atasan masing-masing departemen dan saya sendiri (Wawancara, 2 Agustus 2019)"

Jadi dapat disimpulkan bahwa pada indikator operating prosedures ini sudah berjalan dengan baik karena dari manajemen sudah sangat tegas dalam menegakkan standar operasional ini sehingga seluruh karyawan kontrak merasa puas dengan operating procedures yang ada di Hotel Artotel Sanur Bali.

4.4.10 Kepuasan Kerja Karyawan Kontrak Berdasarkan Communication

Kepuasan kerja karyawan kontrak Hotel Artotel Sanur Bali berdasarkan contingent rewards dapat dilihat dari hasil kuesioner yang dihitung melalui analisis skala likert. Adapun rinciannya dapat dilihat pada tabel berikut.

Tabel 14. Kepuasan Kerja Karyawan Kontrak Hotel Artotel Sa nur Bali Berdasarkan Communication

\begin{tabular}{|l|l|l|l|l|l|l|l|l|l|l|}
\hline \multirow{2}{*}{ No } & \multirow{2}{*}{ Indikator } & \multicolumn{5}{|c|}{ Penilaian } & Skor & $\begin{array}{l}\text { Rata } \\
\text { Rata }\end{array}$ & Kategori \\
\cline { 2 - 9 } & STP & TP & CP & P & SP & \\
\hline 1 & Communication & $\begin{array}{l}\text { Perusa haan memberikan } \\
\text { informasi mengenai standar } \\
\text { memberikan pelayananyang } \\
\text { baik kepada tamu }\end{array}$ & 0 & 0 & 0 & 30 & 33 & 285 & 4,52 & $\begin{array}{l}\text { Sangat } \\
\text { Puas }\end{array}$ \\
\hline b & $\begin{array}{l}\text { Perusahaan selalu } \\
\text { memberikan informasi } \\
\text { terupdate dariluarmaupun } \\
\text { dalam perusahaan } \\
\text { (Artotelgroup/AG) }\end{array}$ & 0 & 0 & 0 & 26 & 37 & 289 & 4,58 & $\begin{array}{l}\text { Sangat } \\
\text { Puas }\end{array}$ \\
\hline \multicolumn{2}{|l|}{ Rata-Rata } & & & & & 287 & 4,55 & $\begin{array}{l}\text { Sangat } \\
\text { Puas }\end{array}$ \\
\hline
\end{tabular}

Sumber:Hasilpenelitian(2019) 
Berdasarkan Tabel 14 di atas, dapat dilihat bahwa indikator Perusahaan memberikan informasi mengenai standar memberikan pelayanan yang baik kepada tamu adat mendapatkan skor 4,52 dengan kategori sangat puas. Indikator kedua yaitu perusahaan selalu memberikan informasi terupdate dari luar maupun dalam perusahaan (Artotelgroup/AG) mendapatkan skor 4,58 dengan kategori sangat puas. Skor rata-rata penilaian karyawan kontrak Hotel Artotel Sanur Bali berdasarkan communication adalah 4,55. Sehingga dapat dikatakan bahwa karyawan kontrak menyatakan sangat puas dengan communication selama bekerja di Hotel Artotel Sanur Bali.

Hasil kuesioner di atas didukung juga oleh hasil wawancara dengan informan yaitu Ibu Maya Putri Septiani selaku Cluster Human Resources Manager sebagai berikut:

"Standar memberikan pelayanan selalu diberitahukan kepada semua karyawan, dan itu masuk dalam training yang dilakukan setiap hari. Semuanya informasi terbar u selalu kami sebar ke grup manajer dulu, baru manajer nantik nyebar ke departemen masingmasing. Makanya informasi itu cepat sampai ke semua karyawan. (Wawancara, 2 Agustus 2019)"

Jadi dapat disimpulkan bahwa pada indikator communication ini sudah berjalan dengan baik karena dari manajemen sudah maksimal memberikan informasi-informasi terbaru sehingga seluruh karyawan kontrak merasa sangat puas dengan communication yang ada di Hotel Artotel Sanur Bali.

3.1.11 Rekapitulasi Kepuasan Kerja Karyawan Kontrak Hotel Artotel Sanur Bali

Rekapitulasi kepuasan kerja karyawan kontrak Hotel Artotel Sanur Bali berdasarkan gaji, pekerjaan itu sendiri, rekan kerja, atasan, promosi, lingkungan kerja, benefit, contingent rewards, operating procedures, dan communication dapat dilihat pada tabel berikut.

Tabel 15. Rekapitulasi Kepuasan Kerja Karyawan Kontrak Hotel ArtotelSanur Bali

\begin{tabular}{|l|l|l|l|l|}
\hline No & Indikator & Total & Rata-rata & Kategori \\
\hline 1 & Gaji & 8,32 & 4,16 & Puas \\
\hline 2 & Pekerjaanitu sendiri & 8,45 & 4,22 & SangatPuas \\
\hline 3 & Rekan kerja & 8,48 & 4,24 & SangatPuas \\
\hline 4 & Atasan & 8,61 & 4,30 & SangatPuas \\
\hline 5 & Promosi & 8,45 & 4,22 & SangatPuas \\
\hline 6 & Lingkungan kerja & 8,55 & 4,27 & SangatPuas \\
\hline 7 & Benefit & 8,35 & 4,17 & Puas \\
\hline 8 & Contingent Rewards & 8,39 & 4,19 & Puas \\
\hline 9 & OperationalProcedures & 9,1 & 4,55 & SangatPuas \\
\hline 10 & Communication & 9,1 & 4,55 & SangatPuas \\
\hline Rata-rata & 8,58 & 4,28 & SangatPuas \\
\hline
\end{tabular}

Sumber:Hasilpenelitian (2019)

Berdasarkan Tabel 15 di atas, menunjukkan bahwa penentu kepuasan kerja karyawan kontrak pada Hotel Artotel Sanur Bali mayoritas dilihat dari indikator Operating Procedures dan Communication yang memiliki rata-rata tertinggi yaitu 4,55, dan disusul oleh indikator atasan dengan rata-rata 4,30 dan indikator lingkungan kerja dengan rata-rata 4,27. Selanjutny a indikator rekan kerja dengan rata-rata 4,24. Disusul oleh indikator pekerjaan itu sendiri dan promosi yang memiliki nilai rata-rata yang sama yaitu 4,22. Indikator gaji, benefit dan contingent rewards mendapatkan rata-rata di bawah 4,21 atau antara 3,41 - 4,20 yang artinya berada pada kategori puas. Ketiga indikator ini belum mencapai kategori sangat puas karena beberapa karyawan merasa belum puas mengenai gaji yang diterima. Selain itu beberapa karyawan juga masih belum puas menganai benefit yang didapat selama bekerja seperti asuransi yang diberikan, pengadaan gathering secara berkala. Ada juga karyawan yang belum mencapai rasa sangat puas mengenai contingent rewards seperti rasa hormat rekan kerja dan atasan dan perusahaan memberikan penghargaan atas prestasi yang dicapai oleh karyawan.

Hasil kuesioner di atas didukung juga oleh hasil wawancara dengan salah satu karyawan yang berada pada Sales \& Marketign Departement sebagai berikut: 
Gaji yang diterima belum begitu sepadan dengan beban kerja yang diberikan (Wawancara, 2 Agustus 2019)"

Jadi dapat disimpulkan bahwa pada indikator gaji hanya mencapai kategori puas dan belum mampu mencapai kategori sangat puas karena masih ada beberapa karyawan yang merasa gaji yang diberikan tidak sepadan dengan beban kerja yang diberikan.

\subsection{Hasil Uji Instrumen}

Uji instrument penelitian ini dilakukan dengan uji validitas dan uji reliabilitas. Instrumen yang akan diuji adalah kuesioner yang berisi 20 pernyataan. Sebuah instrumen dianggap memiliki validitas yang tinggi jika instrumen tersebut benar-benar dapat dijadikan alat untuk mengukur sesuatu secara tepat. Selanjutnya uji reliabilitas untuk mengetahui instrument reliabel bila mampu mengukur sesuatu dengan hasil yang konsisten.

\subsubsection{Uji Validitas}

Uji validitas dilakukan pada semua responden yaitu 63 karyawan kontrak dengan menggunakan taraf signifikan 5\% dengan rtabel 0,300. Adapun hasil uji validitas dapat dilihat pada tabel berikut.

Tabel 16. Hasil Uji Validitas

\begin{tabular}{|c|c|c|c|c|}
\hline VariabelPenelitian & Item & $\begin{array}{l}\text { Koefisien } \\
\text { Korelasi }\end{array}$ & rtabel5\% & Keterangan \\
\hline \multirow{2}{*}{ Gaji } & $\mathrm{X} 1.1$ & 0,527 & 0,300 & Valid \\
\hline & $\mathrm{X} 1.2$ & 0,374 & 0,300 & Valid \\
\hline \multirow{2}{*}{ Pekerjaan itu sendiri } & $\mathrm{X} 2.1$ & 0,592 & 0,300 & Valid \\
\hline & $\mathrm{X} 2.2$ & 0,630 & 0,300 & Valid \\
\hline \multirow{2}{*}{ Rekan Kerja } & $\mathrm{X} 3.1$ & 0,627 & 0,300 & Valid \\
\hline & X3.2 & 0,811 & 0,300 & Valid \\
\hline \multirow{2}{*}{ Atasan } & $\mathrm{X} 4.1$ & 0,788 & 0,300 & Valid \\
\hline & $\mathrm{X} 4.2$ & 0,630 & 0,300 & Valid \\
\hline \multirow{2}{*}{ Promosi } & $\mathrm{X} 5.1$ & 0,531 & 0,300 & Valid \\
\hline & $\mathrm{X} 5.2$ & 0,802 & 0,300 & Valid \\
\hline \multirow{2}{*}{ Lingkungan Kerja } & X6.1 & 0,839 & 0,300 & Valid \\
\hline & X6.2 & 0,837 & 0,300 & Valid \\
\hline \multirow{2}{*}{$\begin{array}{l}\text { Benefit } \\
\text { (Manfaat/Keuntungan) }\end{array}$} & $\mathrm{X} 7.1$ & 0,611 & 0,300 & Valid \\
\hline & $\mathrm{X} 7.2$ & 0,715 & 0,300 & Valid \\
\hline \multirow{2}{*}{ ContigentRewards } & $\mathrm{X} 8.1$ & 0,870 & 0,300 & Valid \\
\hline & $\mathrm{X} 8.2$ & 0,609 & 0,300 & Valid \\
\hline \multirow{2}{*}{$\begin{array}{l}\text { Operating Procedures } \\
\text { (Prosedur Operasional) }\end{array}$} & $\mathrm{X} 9.1$ & 0,707 & 0,300 & Valid \\
\hline & $\mathrm{X} 9.2$ & 0,675 & 0,300 & Valid \\
\hline \multirow{2}{*}{$\begin{array}{l}\text { Communication } \\
\text { (Komunikasi) }\end{array}$} & $\mathrm{X} 10.1$ & 0,621 & 0,300 & Valid \\
\hline & $\mathrm{X} 10.2$ & 0,346 & 0,300 & Valid \\
\hline
\end{tabular}

Sumber: Hasil output SPSS 21.0 (2019)

Berdasarkan hasil uji validitas pada Tabel 16 di atas dapat diketahui bahwa seluruh variabel memiliki nilai korelasi di atas $0,300\left(\mathrm{r}_{\text {tabel }}\right)$. Jika nilai $\mathrm{r}_{\text {hitung }}$ lebih besar dari $\mathrm{r}_{\text {tabel }}$ maka dapat dikatakan valid. Jadi pada penelitian ini hasil olahan data di atas menyatakan bahwa seluruh variabel penelitian dapat digunakan untuk mengukur variabel yang diteliti.

3.2.2 Uji Reliabilitas

Uji Reliabilitas adalah pengujian yang mengukur tingkat konsisten atau kestabilan data kuesioner. Suatu kuesioner dikatakan reliabel atau handal jika jawaban seseorang terhadap pernyataan konsisten dari waktu ke waktu. Reliabilitas diukur dengan uji statistik cronbach's alpha $(\alpha)$. Suatu variabel dikatakan reliabel jika memberikan nilai cronbach' alpha > 0,60 (Imam Ghozali, 2007: 41). Adapun hasil uji reliabilitas dapat dilihat pada tabel berikut. 
Tabel 17. HasilUjiReliabilitas

\begin{tabular}{|c|c|}
\hline Cronbach's Alpha & $\mathrm{N}$ of Items \\
\hline .932 & 20 \\
\hline
\end{tabular}

Sumber: Hasilolah data SPSS 21.0,2019

Berdasarkan Tabel 17 di atas, dapat diketahui bahwa hasil uji reliabilitas pada penelitian ini menunjukkan seluruh variabel penelitian memiliki nilai Alpha Cronbach's lebih besar dari 0,60, artinya masing-masing variabel yang digunakan pada penelitian ini dikatakan reliabel dan layak digunakan pada analisis selanjutnya. Pada penelitian ini, rata-rata nilai alpha cronbach's seluruh variabel penelitian berada di atas 0,900 dan termasuk pada kategori reliabel sangat kuat.

\subsection{Hasil Analisis Faktor Kepuasan Kerja Karyawan Kontrak Hotel Artotel Sanur Bali}

Hasil dari penghipunan data kuesioner yang berjumlah 63 karyawan kontrak yang sebelumnya telah dilakukan uji validitas dan uji reliabilitas, selanjutnya akan dianalisis dengan analisis faktor. Adapun langkah-langkah dan hasil analisis faktor kepuasan kerja karyawan kontrak pada Hotel Artotel Sanur Bali.

\subsubsection{Fa ktor-Faktor Penentu Kepuasan Kerja Karyawan Kontrak Hotel Artotel Sa nur Bali}

Faktor-faktor yang menentukan kepuasan kerja karyawan kontrak Hotel Artotel Sanur Bali dibentuk dari 10 faktor dimana masing-masing faktor terdiri dari dua variabel yang berbeda. Sehingga jika dijumlahkan, maka keseluruhan variabel yang akan diteliti sebanyak 20 variabel. Untuk lebih jelasnya variabel tersebut dijabarkan dalam Tabel 18.

Tabel 18. Deskripsi Variabel

\begin{tabular}{|c|c|c|c|}
\hline No & Faktor & Variabel & Kode Variabel \\
\hline \multirow[t]{2}{*}{1} & \multirow[t]{2}{*}{ Gaji } & Besaran gaji yang diterima & $\mathrm{X} 1.1$ \\
\hline & & Ketepatan waktu menerima gaji & $\mathrm{X} 1.2$ \\
\hline \multirow[t]{2}{*}{2} & \multirow{2}{*}{$\begin{array}{l}\text { Pekerjaan itu } \\
\text { sendiri }\end{array}$} & Pekerjaan yang menyenangkan / tidak membosankan & $\mathrm{X} 2.1$ \\
\hline & & Pekerjaan yang menantang & $\mathrm{X} 2.2$ \\
\hline \multirow[t]{2}{*}{3} & \multirow[t]{2}{*}{ Rekankerja } & Rekan kerja yang menyenangkan & $\mathrm{X} 3.1$ \\
\hline & & $\begin{array}{l}\text { Bekerjasama dengan lancar (bertanggung jawab, } \\
\text { dukungan dari rekan kerja) }\end{array}$ & $\mathrm{X} 3.2$ \\
\hline \multirow[t]{2}{*}{4} & \multirow[t]{2}{*}{ Ata san } & $\begin{array}{l}\text { Atasan senantiasa memberikan petunjuk dalam } \\
\text { melaksanakan pekerjaan }\end{array}$ & $\mathrm{X} 4.1$ \\
\hline & & $\begin{array}{l}\text { Sistem pengawasan tegas dalam menegakkan disiplin } \\
\text { dan secara terus menerus }\end{array}$ & $\mathrm{X} 4.2$ \\
\hline \multirow[t]{2}{*}{5} & \multirow[t]{2}{*}{ Promosi } & Kebijakan promosi yang bagi siapa saja secara adil & X5.1 \\
\hline & & $\begin{array}{l}\text { Manajemen memberikan kesempatan dan memfasilitasi } \\
\text { untuk belajar }\end{array}$ & $\mathrm{X} 5.2$ \\
\hline \multirow[t]{2}{*}{6} & \multirow{2}{*}{$\begin{array}{l}\text { Lingkungan } \\
\text { kerja }\end{array}$} & Lingkungan kerja yang aman dan nyaman & X6.1 \\
\hline & & $\begin{array}{l}\text { Tersedianya fasilitas tempat istirahat, kantin, tempat } \\
\text { ibadah yang nyaman }\end{array}$ & $\mathrm{X} 6.2$ \\
\hline \multirow[t]{2}{*}{7} & \multirow[t]{2}{*}{ Benefit } & Perusahaan memberikan asuransi & $\mathrm{X} 7.1$ \\
\hline & & Perusahaan mengadakan gathering secara berkala & $\mathrm{X} 7.2$ \\
\hline \multirow[t]{2}{*}{8} & \multirow{2}{*}{$\begin{array}{l}\text { Contingent } \\
\text { rewards }\end{array}$} & Rasa hormat kepada rekan kerja dan atasan & $\mathrm{X} 8.1$ \\
\hline & & $\begin{array}{l}\text { Perusahaan memberikan penghargaan atas prestasi yang } \\
\text { didapat oleh karyawan }\end{array}$ & $\mathrm{X} 8.2$ \\
\hline \multirow[t]{2}{*}{9} & \multirow[t]{2}{*}{$\begin{array}{l}\text { Operating } \\
\text { procedures }\end{array}$} & $\begin{array}{l}\text { Adanya aturan standar penampilan dan pemakaian baju } \\
\text { adat }\end{array}$ & $\mathrm{X} 9.1$ \\
\hline & & $\begin{array}{l}\text { Adanyan aturan } \\
\text { pengambilan cuti }\end{array}$ & $\mathrm{X} 9.2$ \\
\hline \multirow[t]{2}{*}{10} & \multirow[t]{2}{*}{ Communication } & $\begin{array}{llc}\begin{array}{l}\text { Perusahaan } \\
\text { mengenai standar }\end{array} & \text { memberikan } & \text { informasi } \\
\text { kepadatamu. } & & \\
\end{array}$ & $\mathrm{X} 10.1$ \\
\hline & & $\begin{array}{l}\text { Perusahaan selalu memberikan informasi ter update dari } \\
\text { luar maupun dalam perusahaan (Artotelgroup/AG) }\end{array}$ & $\mathrm{X} 10.2$ \\
\hline
\end{tabular}

Sumber: Hasil pengolahan data (2019) 


\subsubsection{Menghitung Korelasi antar Variabel}

Mengukur besar korelasi antar variabel merupakan tahap awal dalam analisis faktor. Tahap ini dilakukan untuk mengetahui variabel yang memiliki korelasi maupun yang tidak dengan variabel dependen yang ditentukan. Adapun syarat nilai korelasinya $>0.5$ dengan signifikansi $<0.05$. Hasilnya dapat dilihat pada Tabel 19 berikut.

Tabel 19. Hasil Uji Ka iser Mayer Olkin (KMO) and Bartlett's Test of Sphericity

\begin{tabular}{|l|l|l|}
\hline $\begin{array}{l}\text { Kaiser-Meyer-Olkin Measure of Sampling } \\
\text { Adequacy. }\end{array}$ & .863 \\
\hline & Approx.Chi-Square & 815.180 \\
& df & 190 \\
Bartlett's Test of Sphericity & Sig. & .000 \\
\hline
\end{tabular}

Sumber: Hasiloutput SPSS 21.0 (2019)

Berdasarkan Tabel 19 di atas, dapat diketahui bahwa nilai KMO and Bartlett's Test sebesar 0,863 yang artinya lebih besar dari 0,5 , dengan signifikansi 0,000 lebih $(<0,05)$. Hal ini menunjukkan bahwa dapat dilakukan analisis selanjutnya. Nilai Bartlett's Test of Sphericity adalah 815,180 dan hasil ini menunjukkan bahwa setiap indikator ada korelasi sehingga model faktor dapat digunakan. Sedangkan hasil uji Measure of Sampling Adiquacy (MSA) seluruh variabel yang memiliki 20 indikator dapat dilihat pada Tabel 20 berikut.

Tabel 20. Hasil Uji Mea sure of Sampling Adiquacy (MSA)

\begin{tabular}{|c|c|c|c|c|}
\hline Variabel Penelitian & Item & $\begin{array}{l}\text { Koefisien } \\
\text { Korelasi }\end{array}$ & Nilai batas & Keterangan \\
\hline \multirow{2}{*}{ Gaji } & $\mathrm{X} 1.1$ & 0,832 & 0,50 & Layak \\
\hline & $\mathrm{X} 1.2$ & 0,808 & 0,50 & Layak \\
\hline \multirow{2}{*}{ Pekerjaan itu sendiri } & $\mathrm{X} 2.1$ & 0,878 & 0,50 & Layak \\
\hline & $\mathrm{X} 2.2$ & 0,815 & 0,50 & Layak \\
\hline \multirow{2}{*}{ Rekan Kerja } & $\mathrm{X} 3.1$ & 0,880 & 0,50 & Layak \\
\hline & $\mathrm{X} 3.2$ & 0,848 & 0,50 & Layak \\
\hline \multirow{2}{*}{ Atasan } & $\mathrm{X} 4.1$ & 0,843 & 0,50 & Layak \\
\hline & $\mathrm{X} 4.2$ & 0,789 & 0,50 & Layak \\
\hline \multirow{2}{*}{ Promosi } & $\mathrm{X} 5.1$ & 0,925 & 0,50 & Layak \\
\hline & $\mathrm{X} 5.2$ & 0,900 & 0,50 & Layak \\
\hline \multirow{2}{*}{ Lingkungan Kerja } & $\mathrm{X} 6.1$ & 0,870 & 0,50 & Layak \\
\hline & $\mathrm{X} 6.2$ & 0,899 & 0,50 & Layak \\
\hline \multirow{2}{*}{$\begin{array}{l}\text { Benefit } \\
\text { (Manfaat/Keuntungan) }\end{array}$} & $\mathrm{X} 7.1$ & 0,903 & 0,50 & Layak \\
\hline & $\mathrm{X} 7.2$ & 0,890 & 0,50 & Layak \\
\hline \multirow{2}{*}{ Contigent Rewards } & $\mathrm{X} 8.1$ & 0,890 & 0,50 & Layak \\
\hline & $\mathrm{X} 8.2$ & 0,869 & 0,50 & Layak \\
\hline \multirow{2}{*}{$\begin{array}{l}\text { Operating Procedures } \\
\text { (Prosedur Operasional) }\end{array}$} & X9.1 & 0,820 & 0,50 & Layak \\
\hline & $\mathrm{X} 9.2$ & 0,716 & 0,50 & Layak \\
\hline \multirow{2}{*}{$\begin{array}{l}\text { Communication } \\
\text { (Komunikasi) }\end{array}$} & $\mathrm{X} 10.1$ & 0,872 & 0,50 & Layak \\
\hline & $\mathrm{X} 10.2$ & 0,666 & 0,50 & Layak \\
\hline
\end{tabular}

Sumber: Hasil olahan SPSS 21.0 (2019)

Berdasarkan tabel 20 di atas, dapat diketahui bahwa secara keseluruhan telah memenuhi kriteria MSA > 0,5. Rata-rata nilai seluruh indikator lebih dari 0,666. Hal ini mengindikasikan bahwa variabel masih bisa diprediksi dan menunjukkan adanya hubungan sangat erat antara seluruh indikator. Setelah semua hasil memenuhi syarat maka bisa dilakukan analisis selanjutnya.

\subsubsection{Ekstraksi Faktor (Factoring)}

Tahap ini merupakan tahap inti pada analisis faktor, yakni factoring. Factoring merupakan proses mengekstrak satu atau lebih faktor dari variabelvariabel yang telah lolos pada uji 
variabel sebelumnya. Adapun cara mengetahuinya dengan memperhatikan nilai eigentvalue. Faktor dapat terbentuk apabila nilai eigentvalue $>1$. Eigentvalue menunjukkan kepentingan-kepentingan relatif masing-masing faktor dalam menghitung total varians dari total indikator yang ada. Nilai eigentvalue dapat dilihat pada tabel berikut.

Tabel 21. Hasil UjiTotal Variance Explained

\begin{tabular}{|c|c|c|c|c|c|c|c|c|c|}
\hline \multirow{2}{*}{$\begin{array}{l}\text { Com } \\
\text { pone } \\
\text { nt }\end{array}$} & \multicolumn{3}{|c|}{ Initial Eigenvalues } & \multicolumn{3}{|c|}{$\begin{array}{c}\text { Extraction Sums of Squared } \\
\text { Loadings }\end{array}$} & \multicolumn{3}{|c|}{$\begin{array}{c}\text { Rotation Sums of Squared } \\
\text { Loadings }\end{array}$} \\
\hline & Total & $\begin{array}{c}\% \text { of } \\
\text { Variance }\end{array}$ & $\begin{array}{c}\text { Cumulati } \\
\text { ve } \%\end{array}$ & Total & $\begin{array}{c}\% \text { of } \\
\text { Variance }\end{array}$ & $\begin{array}{c}\text { Cumulati } \\
\text { ve } \%\end{array}$ & Total & $\begin{array}{c}\% \text { of } \\
\text { Variance }\end{array}$ & $\begin{array}{l}\text { Cumulat } \\
\text { ive \% }\end{array}$ \\
\hline 1 & 9.072 & 45.359 & 45.359 & 9.072 & 45.359 & 45.359 & 4.435 & 22.174 & 22.174 \\
\hline 2 & 1.570 & 7.849 & 53.208 & 1.570 & 7.849 & 53.208 & 3.386 & 16.930 & 39.103 \\
\hline 3 & 1.372 & 6.859 & 60.067 & 1.372 & 6.859 & 60.067 & 3.026 & 15.132 & 54.235 \\
\hline 4 & 1.210 & 6.048 & 66.116 & 1.210 & 6.048 & 166.116 & 2.376 & 11.880 & 66.116 \\
\hline 5 & .907 & 4.534 & 70.650 & & & & & & \\
\hline 6 & .864 & 4.320 & 74.970 & & & & & & \\
\hline 7 & .817 & 4.085 & 79.055 & & & & & & \\
\hline 8 & .748 & 3.740 & 82.795 & & & & & & \\
\hline 9 & .657 & 3.285 & 86.080 & & & & & & \\
\hline 10 & .502 & 2.508 & 88.588 & & & & & & \\
\hline 11 & .441 & 2.204 & 90.792 & & & & & & \\
\hline 12 & .404 & 2.019 & 92.811 & & & & & & \\
\hline 13 & .316 & 1.579 & 94.390 & & & & & & \\
\hline 14 & .250 & 1.252 & 95.642 & & & & & & \\
\hline 15 & .232 & 1.161 & 96.804 & & & & & & \\
\hline 16 & .184 & .920 & 97.723 & & & & & & \\
\hline 17 & .155 & .774 & 98.498 & & & & & & \\
\hline 18 & .133 & .664 & 99.162 & & & & & & \\
\hline 19 & .094 & .471 & 99.633 & & & & & & \\
\hline 20 & .073 & .367 & 100.000 & & & & & & \\
\hline
\end{tabular}

Extraction Method: Principal Component Analysis

Sumber: Hasil olahan SPSS 21.0, (2019)

Berdasarkan Tabel 21 di atas, dapat diketahui bahwa dari 20 indikator yang dianalisis hanya terbentuk 4 faktor (component). Faktor 1 memiliki eigenvalue sebesar 9.072 dan varians yang mampu diterangkan oleh faktor 1 adalah 45.360\%. Faktor 2 memiliki eigenvalue sebesar 1.570 dan varians yang mampu diterangkan oleh faktor 2 adalah $7.849 \%$. Faktor 3 memiliki eigenvalue sebesar 1.372 dan varians yang mampu diterangkan oleh faktor 3 adalah $6.859 \%$. Faktor 4 memiliki eigenvalue sebesar 1.210 dan varians yang mampu diterangkan oleh faktor 1 adalah $6.048 \%$.

Total keempat faktor mampu menjelaskan indikator sebesar $45.359 \%+7.849 \%+$ $6.859 \%+6.048 \%=66.116 \%$. Total Varians $66.116 \%$ ini menjelaskan 20 indikator, sedangkan $33.884 \%$ tidak dapat dijelaskan pada penelitian ini. Jumlah eigentvalue 20 indikator adalah sama dengan total varians 20 indikator seperti $9.072+1.570+1.372+1.210+0.907+0.864+0.817+0.748+0.657+0.502+0.441+0.404+0.316+0.250+$ $0.232+0.184+0.155+0.133+0.094+0.073=20$. 
Berikut diagram Scree Plot yang ditunjukkan pada Grafik 1 memperlihatkan bahwa hanya 4 komponen yang memiliki nilai eigenvalue lebih dari 1.

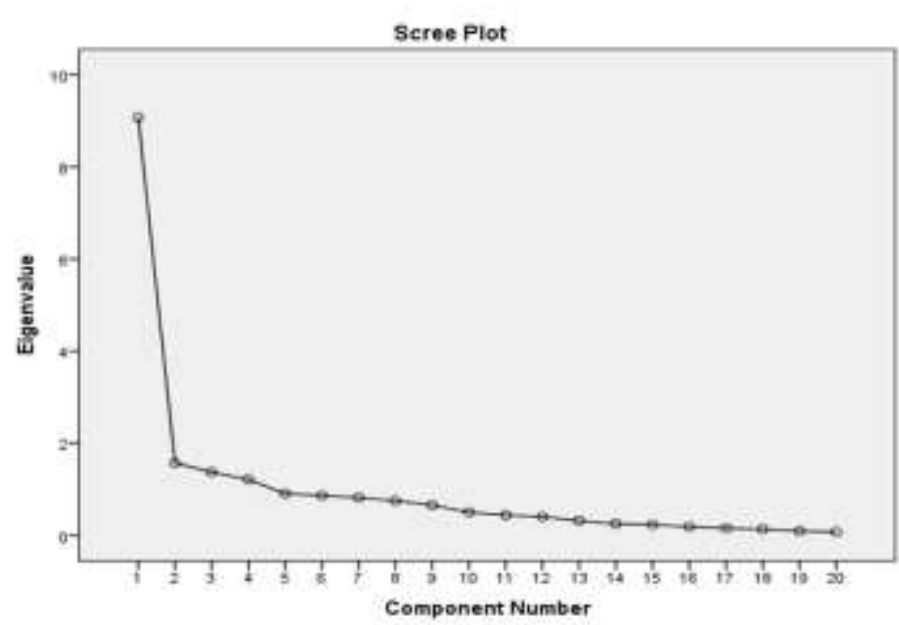

Gambar 1. Scree Plot

Berdasarkan Gambar 1 di atas, dapat dilihat bahwa sumbu $\mathrm{Y}$ adalah eigenvalues, dan pada sumbu $\mathrm{X}$ adalah jumlah komponen yang diukur berdasarkan eigenvalues. Maka dapat diketahui bahwa hanya 4 variabel yang memiliki eigenvalues lebih dari satu. Berdasarkan nilai eigentvalue di atas, maka dapat disimpulakn bahwa hanya 4 faktor yang terbentuk yang memiliki nilai eigenvalue lebih dari satu. Adapun nilai eigentvalue tersebut yaitu 9.072, 1.570, 1.372 dan 1.210. Jadi 4 faktor dari 20 variabel yang dapat menentukan kepuasan kerja karyawan kontrak Hotel Artotel Sanur Bali.

\subsubsection{RotasiFaktor}

Sebuah indikator dinyatakan berperan sebagai pembentuk faktor ditunjukkan oleh nilai loading factor tertinggi. Adapun nilai loading factor tersebut dapat dilihat pada hasil uji rotated component matrix yang dijabarkan pada tabel berikut.

Tabel22. Hasil Uji Rota ted Component Matrix

\begin{tabular}{|c|c|c|c|c|c|}
\hline \multirow{2}{*}{ Indikator } & \multirow{2}{*}{ Variabel } & \multicolumn{4}{|c|}{ Component } \\
\hline & & $\mathbf{1}$ & 2 & 3 & 4 \\
\hline Besaran gaji & \multirow{2}{*}{ Gaji } & .087 & .159 & .805 & .086 \\
\hline Ketepatan waktu gajian & & -.055 & .638 & .116 & .077 \\
\hline Pekerjaanmenyenangkan & \multirow{2}{*}{ Pekerjaanitu sendir } & .545 & .434 & .310 & -.121 \\
\hline Pekerjaanmenantang & & .670 & .240 & .284 & .200 \\
\hline Rekan kerja menyenangkan & \multirow{2}{*}{ Rekankerja } & .243 & .801 & .254 & .045 \\
\hline Bekerjasama la ncar & & \begin{tabular}{|l|l|}
.479 \\
\end{tabular} & .692 & .311 & .032 \\
\hline Ata san memberikan petunjuk & \multirow{2}{*}{ Atasan } & .351 & .474 & .557 & .092 \\
\hline Sistem pengawasan & &.- .013 & .521 & -.085 & .537 \\
\hline Kebiajakan promosi & \multirow{2}{*}{ Promosi } & .159 & .319 & .732 & .120 \\
\hline Fasilita s untukbelajar & & .522 & .569 & .254 & .325 \\
\hline Lingkungan nyaman & \multirow{2}{*}{ Lingkungan kerja } & .510 & .514 & .364 & .292 \\
\hline Fasilita s karyawan & & .554 & .342 & .458 & .377 \\
\hline Asuransi & \multirow{2}{*}{ Benefit } & .559 & -.030 & .565 & .389 \\
\hline Gathering & & .526 & .159 & .322 & .535 \\
\hline Rasa hormat & \multirow{2}{*}{ Contingent Reward } & .526 & .369 & .380 & .484 \\
\hline Penghargaan & & .614 & .102 & .305 & .280 \\
\hline SOP penampilan & \multirow{2}{*}{$\begin{array}{l}\text { Operating } \\
\text { Procedures }\end{array}$} & .815 & -.083 & .135 & -.010 \\
\hline SOP cuti & & \begin{tabular}{|l}
.635 \\
\end{tabular} & .295 & -.239 & .055 \\
\hline Komunikasi & Communication & .300 & .125 & .019 & .540 \\
\hline
\end{tabular}


Informasibaru \begin{tabular}{|l|l|}
\hline-.043 & -.049 \\
\hline
\end{tabular}

.177
.784

Extraction Method: Principal Component Analysis. Rotation

Method: Varimax with Kaiser Normalization. ${ }^{\mathrm{a}}$ a. Rotation converged in 7 iterations.

Sumber:Hasil olah SPSS 21.0 (2019)

Berdasarkan Tabel 22 di atas, dapat diketahui bahwa indikator pekerjaan menyenangkan, pekerjaan menantang, fasilitas karyawan, rasa hormat, penghargaan, SOP penampilan dan SOP cuti mempunyai nilai loading factor tertinggi dalam bentuk faktor 1. Indikator ketepatan waktu gajian, rekan kerja menyenangkan, bekerjasama lancar, fasilitas belajar dan lingkungan nyaman mempunyai nilai loading factor tertinggi dalam bentuk faktor 2. Indikator besaran gaji, atasan memberikan petunjuk kebijakan promosi dan asuransi mempunyai nilai loading factor tertinggi dalam bentuk faktor 3. Indikator sistem pengawasan, gathering, komunikasi lancar dan informasi terbaru mempunyai nilai loading factor tertinggi dalam bentuk faktor 4. Adapun anggota masing masing faktor jika dikelompokkan dijabarkan pada tabel berikut:

Tabel23. Anggota Masing-Masing Fa ktor

\begin{tabular}{|c|c|c|c|}
\hline No & Faktor & Anggota & Keterangan \\
\hline \multirow{7}{*}{1} & \multirow{7}{*}{ Faktor 1} & $\mathrm{X} 2.1$ & Pekerjaanyang menyenangkan/tidak membosankan \\
\hline & & $\mathrm{X} 2.2$ & Pekerjaan yang menantang \\
\hline & & $\mathrm{X} 6.2$ & $\begin{array}{l}\text { Tersedia nya fasilitas tempat istira hat, kantin, te mpat } \\
\text { ibadah yang nyaman }\end{array}$ \\
\hline & & $\mathrm{X} 8.1$ & Rasa hormat kepadarekan kerja dan atasan \\
\hline & & $\mathrm{X} 8.2$ & $\begin{array}{l}\text { Perusahaan memberikan penghargaan atas pre stasi } \\
\text { yang didapat oleh karyawan }\end{array}$ \\
\hline & & $\mathrm{X} 9.1$ & $\begin{array}{l}\text { Ada nya a turan standar penampilan d an pe makaian } \\
\text { baju adat }\end{array}$ \\
\hline & & $\mathrm{X} 9.2$ & Ada nyan aturan dalam bekerja dan pengambilan cuti \\
\hline \multirow{5}{*}{2} & \multirow{5}{*}{ Faktor 2} & $\mathrm{X} 1.2$ & Ketepatan waktu menerima gaji \\
\hline & & $\mathrm{X} 3.1$ & Rekan kerja yang menyenangkan \\
\hline & & $\mathrm{X} 3.2$ & $\begin{array}{l}\text { Bekerja sama dengan la ncar (bertanggung ja wab, } \\
\text { dukungan dari rekan kerja) }\end{array}$ \\
\hline & & $\mathrm{X} 5.2$ & $\begin{array}{l}\text { Manajemen memberikan } \\
\text { memfasilitasiuntukbelajar }\end{array}$ \\
\hline & & $\mathrm{X} 6.1$ & Lingkungan kerja yang aman dan nyaman \\
\hline \multirow{4}{*}{3} & \multirow{4}{*}{ Faktor 3} & $\mathrm{X} 1.1$ & Besaran gaji yang diterima \\
\hline & & $\mathrm{X} 4.1$ & $\begin{array}{l}\text { Atasan senantiasa memberikan petunjuk dalam } \\
\text { melaksanakan pekerjaan }\end{array}$ \\
\hline & & $\mathrm{X} 5.1$ & Kebijakan promosi yang bagi siapa sa ja secara adil \\
\hline & & $\mathrm{X} 7.1$ & Perusahaan memberikan asuransi \\
\hline \multirow{4}{*}{4} & \multirow{4}{*}{ Faktor 4} & $\mathrm{X} 4.2$ & $\begin{array}{l}\text { Sistem pengawasan tegas dalam menegakkan disiplin } \\
\text { dan secara terus menerus }\end{array}$ \\
\hline & & $\mathrm{X} 7.2$ & Perusahaan mengadakan gathering secara berkala \\
\hline & & $\mathrm{X} 10.1$ & $\begin{array}{l}\text { Perusahaan memberikan informasimengenai standar } \\
\text { memberikan pelayanan yang baik kepada tamu }\end{array}$ \\
\hline & & $\mathrm{X} 10.2$ & $\begin{array}{l}\text { Perusahaanselalu memberikan informasi terupdate } \\
\text { dari luar maupun dalam perusahaan } \\
\text { (Artotelgroup/AG) }\end{array}$ \\
\hline
\end{tabular}

Sumber:Hasil olahan data, 2019

\subsubsection{Interpretasi Faktor}

Interpretasi faktor adalah tahap pemberian nama atas faktor yang terbentuk setelah melakukan ekstraksi faktor (factoring) dan rotasi faktor. 4 faktor yang terbentuk pada proses factoring akan diberikan nama yang dianggap bisa mewakili variabel-variabel anggota faktor 
tersebut. Pemberian nama dan konsep pada tiap faktor ditentukan berdasarkan makna umum variabel yang tercakup didalamnya.

bawah ini

Adapun pemberian nama pada keempat faktor tersebut dapat dilihat pada Tabel 24 di

Tabel24. Penamaan Faktor

\begin{tabular}{|c|c|c|c|c|c|}
\hline $\begin{array}{l}\text { Fakt } \\
\text { or }\end{array}$ & Variabel & $\begin{array}{l}\text { Nama } \\
\text { Faktor }\end{array}$ & $\begin{array}{l}\text { Eigenv } \\
\text { alue }\end{array}$ & $\begin{array}{l}\text { Loadin } \\
\text { g } \\
\text { Factor }\end{array}$ & $\begin{array}{l}\text { \%of } \\
\text { Variance }\end{array}$ \\
\hline \multirow{7}{*}{1} & $\begin{array}{l}\text { X2.1 Pekerjaan yang } \\
\text { menyenangkan/tidak membosankan }\end{array}$ & \multirow{7}{*}{$\begin{array}{l}\text { Faktor } \\
\text { Individu dan } \\
\text { Kebijakan } \\
\text { Perusahaan }\end{array}$} & \multirow{7}{*}{9.072} & 0.545 & \multirow{7}{*}{45.359} \\
\hline & $\mathrm{X} 2.2$ Pekerjaan y ang menantang & & & 0.670 & \\
\hline & $\begin{array}{l}\text { X6.2 Tersedianya fasilitas tempatist ira hat, } \\
\text { kantin, tempat ibadahyang } \\
\text { nya man }\end{array}$ & & & 0.554 & \\
\hline & $\begin{array}{l}\text { X8.1 Ra sa hormat kepada rek an kerja d an } \\
\text { ata san }\end{array}$ & & & 0.526 & \\
\hline & $\begin{array}{l}\text { X8.2 Perusahaan memberikan pengh argaan } \\
\text { atas prestasi yang didapat oleh karyawan }\end{array}$ & & & 0.614 & \\
\hline & $\begin{array}{l}\text { X9.1 Adanya aturan standar penampilan dan } \\
\text { pemakaian baju adat }\end{array}$ & & & 0.815 & \\
\hline & $\begin{array}{l}\text { X9.2 Adanyan aturan dalam bekerja dan } \\
\text { pengambilan cuti }\end{array}$ & & & 0.635 & \\
\hline \multirow{5}{*}{2} & X1.2 Ketepatan waktu menerima gaji & \multirow{5}{*}{$\begin{array}{l}\text { Faktor } \\
\text { Sosial dan } \\
\text { Promosi }\end{array}$} & \multirow{5}{*}{1.570} & 0.638 & \multirow{5}{*}{7.849} \\
\hline & X3.1 Rekan kerja yang menyenangkan & & & 0.801 & \\
\hline & $\begin{array}{l}\text { X3.2 Bekerjasama dengan lancar } \\
\text { (bertanggungja wab, dukungan dari rekan } \\
\text { kerja) }\end{array}$ & & & 0.692 & \\
\hline & $\begin{array}{l}\text { X5.2 Manajemen memberikan kesempatan } \\
\text { dan memfasilitasiuntuk belajar }\end{array}$ & & & 0.569 & \\
\hline & $\begin{array}{l}\text { X6.1 Lingkungan kerja yang aman da } \mathrm{n} \\
\text { nyaman }\end{array}$ & & & 0.514 & \\
\hline \multirow{4}{*}{3} & X1.1 Besaran gaji yang diterima & \multirow{4}{*}{$\begin{array}{l}\text { Faktor } \\
\text { Organisasi } \\
\text { dan } \\
\text { Manajemen }\end{array}$} & \multirow{4}{*}{1.372} & 0.805 & \multirow{4}{*}{6.859} \\
\hline & $\begin{array}{l}\text { X4.1 Atasan senantiasa memberikan } \\
\text { petunjuk dalam melaksanakan } \\
\text { pekerjaan }\end{array}$ & & & 0.557 & \\
\hline & $\begin{array}{l}\text { X5.1 Kebijakan promosi yang ba gi siapa saja } \\
\text { secara adil }\end{array}$ & & & 0.732 & \\
\hline & X7.1 Perusahaan memberikan asuransi & & & 0.565 & \\
\hline \multirow{4}{*}{4} & $\begin{array}{l}\text { X4.2 Sistem pengawasan tegas dalam } \\
\text { menegakkan disiplin dan secara terus } \\
\text { menerus }\end{array}$ & \multirow{4}{*}{$\begin{array}{l}\text { Faktor } \\
\text { Atasan dan } \\
\text { Komunikasi }\end{array}$} & \multirow{4}{*}{1.210} & 0.537 & \multirow{4}{*}{6.048} \\
\hline & $\begin{array}{l}\text { X7.2 Perusahaan mengadakan gathering } \\
\text { secara berkala }\end{array}$ & & & 0.535 & \\
\hline & $\begin{array}{l}\text { X10.1 Perusahaan memberikan informasi } \\
\text { mengenai standar memberikan pelayanan } \\
\text { yangbaik kepada tamu }\end{array}$ & & & 0.540 & \\
\hline & $\begin{array}{l}\text { X10.2 Perusahaan selalu memberikan } \\
\text { informasi terupdate dari luar maupun } \\
\text { dalam perusahaan (Artotelgroup/AG) }\end{array}$ & & & 0.784 & \\
\hline
\end{tabular}

Sumber: Hasil olah data, 2019

Berdasarkan Tabel 24 di atas, dapat dilihat bahwa:

a. Faktor pertama memiliki 7 indikator yang memiliki korelasi terbesar pada faktor tersebut dapat dilihat pada Tabel 22 Sehingga dinyatakan mampu mewakili 7 indikator tersebut, yang terdiri dari 1) Pekerjaan yang menyenangkan/tidak membosankan; 2) Pekerjaan yang menantang; 3) Tersedianya fasilitas tempat istirahat, kantin, tempat ibadah yang nyaman; 4) 
Rasa hormat kepada rekan kerja dan atasan; 5) Perusahaan memberikan penghargaan atas prestasi yang didapat oleh karyawan; 6) Adanya aturan standar penampilan dan pemakaian baju adat; 7) Adanya aturan dalam bekerja dan pengambilan cuti.

b. Faktor kedua memiliki 5 indikator yang memiliki korelasi terbesar pada faktor tersebut dapat dilihat pada tabel Tabel 22. Sehingga dinyatakan mampu mewakili 5 variabel terse but, yang terdiri dari 1) Ketepatan waktu menerima gaji; 2) Rekan kerja yang menyenangkan; 3) Bekerjasama dengan lancar (bertanggung jawab, dukungan dari rekan kerja); 4) Manajemen memberikan kesempatan dan memfasilitasi untuk belajar; 5) Lingkungan kerja yang aman dan nyaman.

c. Faktor ketiga memiliki 4 indikator yang memiliki korelasi terbesar pada faktor tersebut dapat dilihat pada Tabel 22. Sehingga dinyatakan mampu mewakili 3 variabel tersebut, yang terdiri dari 1) Besaran gaji yang diterima; 2) Atasan senantiasa memberikan petunjuk dalam melaksanakan pekerjaan; 3) Kebijakan promosi yang bagi siapa saja secara adil; 4) Perusahaan memberikan asuransi.

d. Faktor keempat memiliki 4 indikator yang memiliki korelasi terbesar pada faktor tersebut dapat dilihat pada Tabel 22. Sehingga dinyatakan mampu mewakili 3 variabel tersebut, yang terdiri dari 1) Sistem pengawasan tegas dalam menegakkan disiplin dan secara terus menerus; 2) Perusahaan mengadakan gathering secara berkala; 3) Perusahaan memberikan informasi mengenai standar memberikan pelayanan yang baik kepada tamu; 4) Perusahaan selalu memberikan informasi terbaru dari luar maupun dalam perusahaan (Artotelgroup/AG).

Interpretasi faktor ini sudah mampu memberikan rangkuman bahwa 20 indikator dapat dijelaskan oleh empat faktor baru yang terbentuk. Hasil analisis faktor ini didukung juga oleh hasil wawancara dengan Ibu Maya selaku Cluster Human Resources Manager yang secara umum hasilnya positif seperti pemberian gaji yang tepat waktu, sistem pengawasan yang tegas dan berkala, pemberian fasilitas belajar yang adil, fasilitas karyawan yang sudah cukup nyamanberbagai jenis asuransi, adanya rasa hormat serta perusahaan selalu memberikan infor masi yang diperlukan karyawan secara cepat. Sehingga hasil analisis faktor ini cukup jelas dan akurat.

Hasil Keempat faktor yang terbentuk tersebut mampu menjelaskan $66.116 \%$ faktor penentu kepuasan kerja karyawan kontrak Hotel Artotel Sanur Bali. Sebesar 33.884\% tidak dapat dijelaskan pada penelitian ini.

\subsection{Faktor Dominan Penentu Kepuasan Kerja Karyawan Kontrak Hotel Artotel Sanur Bali}

Berdasarkan pengolahan data melalui SPSS 21.0 pada penelitian ini, terdapat 4 faktor yang terbentuk. Untubbk menentukan faktor dominan dengan mengacu pada total nilai varians tertinggi yang dapat dilihat pada tabel total variance explained. Dari empat faktor yang terbentuk tersebut, faktor satu memiliki nilai percentage of variance yang tertinggi yaitu 45.359. Sehingga faktor pertama ini dinyatakan sebagai faktor dominan yang mampu menentukan kepuasan kerja karyawan kontrak pada Hotel Artotel Sanur Bali.

\section{KESIMPULAN}

Berdasarkan hasil dan pembahasan yang telah dipaparkan mengenai kepuasan kerja karyawan kontrak pada Hotel Artotel Sanur Bali yang telah dibahas di atas maka dapat disimpulkan bahwa: 1) Terdapat 4 faktor yang terbentuk dari 20 variabel yang dianalisis melalui analisis faktor. Adapun keempat faktor yang menentukan kepuasan kerja karyawan kontrak pada Hotel Artotel Sanur Bali yaitu faktor individu dan kebijakan perusahaan, faktor sosial dan promosi, faktor organisasi dan manajemen, serta faktor atasan dan komunikasi. Keempat faktor di tersebut mampu menjelaskan $66.116 \%$ faktor yang menentukan kepuasan kerja karyawan kontrak pada Hotel Artotel Sanur Bali dan 33,884 \% merupakan faktor lain yang tidak mampu dijelaskan pada penelitian ini; 2) Faktor dominan yang pada penelitian ini adalah faktor satu yaitu faktor individu dan kebijakan perusahaan. Hal ini dapat dilihat dari nilai percentage of variance yang tertinggi yaitu 45.359 yang dimiliki oleh faktor individu dan kebijakan perusahaan, sehingga faktor ini dinyatakan sebagai faktor dominan yang mampu menentukan kepuasan kerja karyawan kontrak pada Hotel Artotel Sanur Bali. 


\section{Ucapan Terima Kasih}

Penulis mengucapkan terima kasih kepada pihak-pihak yang sudah terlibat dalam penuliasan laporan ini diantaranya Universitas Udayana tempat penulis menempuh pendidikan. Juga kepada Dr. Drs. I Nyoman Sunarta, M.Si. Selaku Dekan Fakultas Pariwisata, Ibu Dra. Anak Agung Putri Sri, M.Si. Selaku Koordinator Program Studi Diploma IV Pariwisata, Fakultas Pariwisata, Universitas Udayana, Ibu Ni Nyoman Sri Aryanti, SST.Par., M.Par. selaku pembimbing akademik yang telah membimbing selama proses perkuliahan, Ibu Ni Made Ariani, SE. M.Par., selaku dosen pembimbing I Laporan Tugas Akhir yang telah membimbing, memberikan saran dan masukan bagi laporan ini, Ibu Ni Putu Ratih Pertiwi, S.ST.Par. M.Par. selaku dosen pembimbing II Laporan Tugas Akhir yang juga telah membimbing, memberikan saran dan masukan bagi laporan ini dan seluruh dosen Fakultas Pariwisata Universitas Udayana yang tidak dapat penulis sebutkan satu-persatu, yang telah mendidik dan memberikan ilmunya kepada penulis. Selanjutnya penulis mengucapkan terima kasih kepada segenap karyawan kontrak Hotel Artotel Sanur Bali yang telah memberikan izin, informasi dan data pada penelitian ini.

\section{DAFTAR PUSTAKA}

Giese, J.L.and J.A.Cote. (2000) Defining Customer Satisfaction,Academy of Marketing Science Review.

Manullang, (2002) Dasar-Dasar Manajemen. Ghalia : Indonesia.

Robbins, Stephen P. (2001) Perilaku Organisasi: Konsep, Kontroversi, Aplikasi, Jilid 1, Edisi 8, Prenhallindo, Jakarta.

Robbins, Stephen P and Mary Coulter (2009). Manajemen. Pearson. United State America. Edisi Kedelapan Jilid 2.

Robinson dan Corners. (2000) Manajemen (edisi 7). Jakarta: PT. Indeks Group Gramedia.

Roseman, E. 1981. Managing turnover: A Positive Approach. New York: Amacom.

Santoso, Singgih. (2018) Mahir Statistik Multivariat dengan SPSS. Jakarta: PT Elex Media Komputindo.

Sihite, Richard. (2000) Food Product (Dasar- DasarTata Boga). Surabaya: Penerbit SIC.

Simamora, Bilson. (2004) Panduan Riset Perilaku Konsumen. Jakarta: Gramedia.

Sudaryono, Yoyo, dkk. (2018) Manajemen Sumber Daya Manusia, Kompensasi Tidak LAngsung dan Lingkungan Kerja Fisik. Yogyakarta: CV Andi Offset.

Sugiyono. (2002) Statistik untuk Penelitian dan Aplikasinya dengan SPSS 10 for Windows. Bandung: Alfabeta. 